\title{
An empirical note on tourism and sustainable development nexus
}

\author{
Mehmet Akif Destek ${ }^{1}\left(\mathbb{D} \cdot\right.$ Sercan Aydın $^{1}$ (D) \\ Received: 9 September 2021 / Accepted: 23 December 2021 / Published online: 17 January 2022 \\ (c) The Author(s), under exclusive licence to Springer-Verlag GmbH Germany, part of Springer Nature 2022
}

\begin{abstract}
The goal of this research is to investigate the impact of tourism on sustainable development in the 10 most visited countries. For this purpose, following the STIRPAT model, the impact of urbanization, energy intensity, and tourism on the newly designed sustainable development index is examined for the period 1995-2015. In doing so, tourism is represented by two different indicators, the number of tourists and tourism receipts. In addition, the impact of tourism on economic growth is analyzed to compare the effects of tourism development on economic growth and sustainable development. While doing this, second-generation panel data methods are used to take into account the possible inter-country dependency. According to the findings obtained in the study, tourism, energy intensity, and urbanization have positive effects on economic growth. On the other hand, the effects of all three factors on the sustainable development index are negative and statistically significant. These findings indicate that the harmful effects of tourism on other dimensions of sustainable development are greater than the beneficial effects of tourism on economic growth.
\end{abstract}

Keywords Tourist arrivals $\cdot$ Sustainable development index $\cdot$ Energy intensity $\cdot$ Urbanization $\cdot$ Panel data

\section{Introduction}

Despite the economic crisis, natural disasters, and epidemics that have plagued the world in recent decades, tourism is one of the fastest growing industries. It is argued that quick improvement in the tourism sector contributes significantly to the economic performance of both developed and developing countries (Eyuboglu and Uzar, 2020). In fact, the World Travel and Tourism Council explained the role of travel and tourism in the growth of the global economy with stating that travel and tourism's total contribution to the global economy in 2019 increased to $10.4 \%$ of global GDP (US\$ 9.2 trillion). Furthermore, the tourism industry appears to be developing at a quicker rate than other important industries such as financial and business services, transportation, and manufacturing (WTTC, 2019). Furthermore,

Responsible Editor: Philippe Garrigues

Mehmet Akif Destek

adestek@gantep.edu.tr

Sercan Aydın

sercanaydin@gantep.edu.tr

1 Department of Economics, Gaziantep University, Gaziantep, Turkey scholars have used empirical analysis to demonstrate the impact of international tourism to economic growth. For instance, Balaguer and Cantavella-Jorda (2002), Durbarry (2002), Dritsakis (2004), Eugenio-Martin et al. (2004), Gunduz and Hatemi (2005), Ongan and Demiroz (2005), Kim et al. (2006), Lee and Chang (2008), Narayan et al. (2010), Dritsakis (2012), Cárdenas-García et al. (2013), Massidda and Mattana (2013), and Du et al. (2016) validated the positive long-run impact of tourism on economic growth.

There have been debates in recent years about how international tourism has indirect effects on long-term economic growth through various routes, as well as direct affects on economic growth. The required foreign exchange input channel is the first indirect effect of tourism. It is well recognized that the growth of tourism is a significant source of foreign cash, allowing payment for imported capital goods or inputs utilized in the manufacturing process (Habibi et al. 2018). In fact, despite emerging economies' concerted attempts to enhance exports, adequate foreign exchange flow cannot be achieved through exports, and as a result, tourism is increasingly considered as a savior for these countries (Durbarry, 2004). The employment channel is the second indirect effect of tourism. Third-world countries have begun to use international tourism as a strategy to maintain peace, eliminate poverty, and improve societal welfare in 
the post-globalization period (Manzoor et al. 2019). Positive externalities to other sectors are the third indirect contribution. That is, the economy has profited from the increase of industrial and agricultural production to meet the growing number of tourists, as well as investments in sectors like as business, transportation, telecommunications, finance, and tourism. Finally, the income distribution route is claimed to be the fourth indirect contribution. Tourism earnings spreading across a vast population layer and the employment of relatively unskilled workers in the tourism sector can have a positive impact on income distribution and consequently economic growth (Basarir and Cakir, 2015).

Despite the fact that many researches have demonstrated the positive influence of tourism on economic growth, the impact of tourism on the environment has spawned a new conversation subject. Despite the fact that countries' economic growth has accelerated and the number of new employment areas has increased in tandem with developments in the tourism sector, the tourism sector has caused environmental destruction in recent years as a result of increased $\mathrm{CO} 2$ emissions due to high energy consumption (Shi et al. 2019; Usman et al. 2020). Although most attempts to explain global warming are focused on energy and fossil fuel consumption, it is a research topic to see if tourism, commonly known as the "smokeless industry," leads to environmental degradation. To put it another way, it is stated that a clean environment is impossible to achieve without embracing sustainable tourism. In reality, the fact that the degradation of the natural environment owing to human activities and the increase in the proportion of tourism in national income have occurred in lockstep over the previous decade is often regarded as a sign of this situation (Stefănica and Butnaru, 2015). While the movement of millions of people living in many locations and settings provides economic opportunities, the entry of new places and ecosystems into the tourist sector may result in environmental deterioration. This rapid expansion in foreign tourism, combined with an increase in domestic tourism, has put pressure on natural resources and habitats such as soil, water, and biodiversity, highlighting the significance of sustainable tourism (Hunter and Green, 1995).

Tourism's two most well-known detrimental consequences on the environment are resource use and pollution. To begin with, the growth of tourism has highlighted the need for new usage areas, and the construction of new touristic places poses a threat to many natural resource regions such as soil and water. Aside from such negative effects on resource usage, the most significant negative effect of tourism is unquestionably pollution. Excessive population growth in tourism locations during certain periods can result in a variety of environmental problems, including water, air, and noise pollution (Farajrad and Aghajan, 2010). The tourism industry requires an air transportation and lodging infrastructure that produces more carbon dioxide and greenhouse gas emissions and consumes a lot of energy. According to research looking into the environmental effects of tourism, the tourist industry accounts for $5 \%$ of global $\mathrm{CO} 2$ emissions (Zhang and Gao, 2016). As a result, academics have turned to studies in recent studies to explain the contribution of tourism to total carbon emissions. For instance, Lee and Brahmasrene (2013), Solarin (2014), Jebli et al. (2015), Zaman et al. (2016), Shakouri et al. (2017), Tang et al. (2018), Zhang and Liu (2019), and Kocak et al. (2020) empirically validated the carbon emissions increasing impact of tourism.

In light of the foregoing considerations, despite the widespread belief that tourism contributes to economic growth while having detrimental effects on environmental quality, it is unclear to what degree the positive economic benefit compensates for the negative environmental impact. In other words, the impact of tourism development, which is thought to be beneficial to economic growth, on long-term development remains unknown. The validity of a probable link between tourism and sustainable development, on the other hand, is well established. Tourism can have good or negative effects on national climate pledges and sustainable development objectives, and it can be affected by these goals and obligations, according to the Paris Agreement (Scott et al., 2016). That is, the Goal 8 of sustainable development, decent work, and economic growth; Goal 12 on responsible consumption and conservation; and Goal 14 on the sustainable use of oceans and seas demonstrate the link between sustainable development and tourism (UNWTO, 2015).

Based on above discussions, the goal of this research is to find out what long-term consequences tourism development has on sustainable development. While doing so, the top 10 most visited countries are discussed in order to see how tourism affects them. The reason why the 10 most visited countries are included in the study is that selected countries are responsible for 55\% of world carbon emissions (WDI, 2021), $40 \%$ of all global tourists visit these countries, and almost $50 \%$ of global tourism revenues are owned by these countries (UNWTO, 2015). In addition, another reason for taking this group of countries is that it is believed that data from developed or emerging tourism-oriented economies can provide more general information on the environmental impacts of environmental management capabilities. Furthermore, empirical models measuring the effects of tourism on real GDP are examined in order to assess the effects of tourism on sustainable development and economic growth. Second-generation panel data estimators that allow crosssection dependence are employed in the empirical analysis phase to account for probable country dependence while determining long-term effects. The findings reveal that, while tourist expansion improves a country's economic 
performance, it has a negative impact on the country's sustainable development.

This study's potential contribution to the literature is as follows: (i) This is the first study to look at how tourism affects sustainable development. (ii) The study's focus on the top ten most visited countries allows for a more thorough examination of tourism's consequences. (iii) By deconstructing the effects of tourism on economic growth and sustainable development, the study enables for comparison. (iv) The study's conclusions are more robust due to the inclusion of two different measures (number of tourists and tourism earnings) as indicators of tourism development. (v) Empirical analyses using second-generation panel data methodologies allow for cross-country dependency, resulting in more consistent conclusions. (vi) While examining the effects of tourism in empirical analysis, some important aspects that are thought to affect sustainable development were added to the model as independent variables, and a possible omitted variable bias was solved.

\section{Literature review}

Since one of the most important dimensions of sustainable development is economic growth, in the first stage of the literature review, studies investigating the relationship between tourism and economic growth are primarily included. As a summarized in Table 1, despite the general opinion that the development of tourism has positive effects on the economic growth performance of countries, few empirical studies have also found that tourism has negative reflections on real GDP. For example, Sequeira and Campos (2005) and Mohapatra (2018) found that the development of tourism harms economic activities. On the other hand, the findings of Balaguer and Cantavella-Jorda (2002), the pioneering study of the "tourism-led growth hypothesis," which argues that tourism activities have an impact on economic growth through spillover effects and other positive externalities, were confirmed by most empirical studies in later years. Wickremasinghe and Ihalanayake (2006), Bilen et al. (2007), Chen and Chiou-Wei (2009), Lee and Brahmasrene (2013), Balcilar et al. (2014), Jambor and Leitão (2017), Sokhanvar (2019), Balsalobre-Lorente et al. (2020), Tu and Zhang (2020), Su et al. (2021), Adedoyin et al. (2021a, b, ), and Rasool et al. (2021) proved the view that there is a positive relationship between tourism revenues and economic growth and the validity of the tourism-based growth hypothesis.

The effects of tourism on environmental sustainability, which is another important dimension of sustainable development, have also become an important research topic in recent years. We summarize the literature on mentioned relationship in Table 2. As a seen, in most of these studies, it is claimed that the tourism sector meets almost all of its energy needs from fossil resources such as oil, natural gas, and coal, and it is claimed that this fossil fuel dependency harms environmental quality. Especially in recent years, developments in the aviation sector for tourism purposes cause an increase in global $\mathrm{CO} 2$ emissions. In addition, the tourism sector needs high energy to meet the increasing food demand and clean up human-made waste. Indeed, Durbarry and Seetanah (2014), Al-Mulali et al. (2015), Ng et al. (2016), Sharif et al. (2017), Nepal et al. (2019), Khan et al. (2020), Setareh et al. (2020), and Jayasinghe and Selvanathan (2021) reached results confirming the view that there is a negative relationship between tourism revenues and environmental quality. On the other hand, there are studies that claim and determine that the transformation into sustainable tourism through environmentally sensitive practices in the tourism sector can contribute to the environment. For example, Lee and Brahmasrene (2013), Jahromi et al. (2017), Jebli and Hadhri (2018), Jebli et al. (2019), Katircioglu et al. (2018), Kongbuama et al. (2020), Lee and Chen (2021), and Khan and Hou (2021) reveal that there is a positive relationship between tourism revenues and environmental quality. On the other hand, Liu et al. (2019) and Oad et al. (2021), it has been argued that tourism does not have a significant impact on the environment.

When all of the studies on the economic and environmental effects of tourism are considered together, mixed results are found for both the economic and environmental effects of tourism. This could be attributable to methodological variations as well as observed country/country group differences. Because the key topic to be investigated is the long-term effects of tourism, studies using methodologies such as GMM and OLS are acknowledged to be insufficient in terms of long-term effects in the literature. On the other hand, it is clear that in research looking at long-term consequences, the inter-country interdependence, or, to put it another way, the cross-sectional dependence, is neglected. As a result, the fact that the methodologies utilized in this study incorporate both long-term estimates and account for cross-sectional dependence distinguishes this study from others in the literature. Furthermore, the positive or negative influence of tourism on only one of the variables stated does not provide meaningful information regarding tourism's impact on long-term growth. As a result, rather than looking at the impact of tourism on a single variable, determining the impact on the sustainable development index, which is made up of a variety of components, will fill a significant gap in the literature.

\section{Empirical strategy}

\section{Model and data}

Since the main purpose of this study is to observe the effects of tourism development on sustainable development, which 
Table 1 Summary of recent literature on the tourism-economic growth nexus

\begin{tabular}{|c|c|c|c|c|c|c|}
\hline Author(s) & Period & Countries & Methodologies & $\begin{array}{l}\text { Dependent } \\
\text { variable }\end{array}$ & Independent variable & Conclusion \\
\hline $\begin{array}{l}\text { Balaguer and Cantavella- } \\
\text { Jorda (2002) }\end{array}$ & 1975-1997 & Spain & VAR & GDP & TOUSA, L & TOUSA increases GDP \\
\hline $\begin{array}{l}\text { Sequeira and Campos } \\
\text { (2005) }\end{array}$ & 1980-1999 & $\begin{array}{l}\text { Tourism-specialized } \\
\text { countries }\end{array}$ & OLS & GDP & TR, GC, INV & TR reduces GDP \\
\hline $\begin{array}{l}\text { Wickremasinghe and } \\
\text { Ihalanayake (2006) }\end{array}$ & $1960-2000$ & Sri Lanka & VECM & GDP & TR & TR increases GDP \\
\hline Bilen et al. (2007) & 1995-2012 & $\begin{array}{l}12 \text { Mediterranean coun- } \\
\text { tries }\end{array}$ & GLS & GDP & TR & TR increases GDP \\
\hline Sequeira and Nunes (2008) & 1980-2002 & $\begin{array}{l}\text { Tourism-specialized } \\
\text { countries }\end{array}$ & GMM & GDP & TR, TA & TR and TA increase GDP \\
\hline $\begin{array}{l}\text { Chen and Chiou-Wei } \\
\text { (2009) }\end{array}$ & 1975-2007 & Taiwan and South Korea & EGARCH & GDP & EXC, R & $\mathrm{R}$ increases GDP \\
\hline Narayan et al. (2010) & 1988-2004 & Pacific Island countries & VAR & GDP & $\mathrm{TE}$ & TE increases GDP \\
\hline Nissan et al. (2011) & $2000-2005$ & 11 countries & OLS & GDP & PE, INV, HC, TOUR & TOUR increases GDP \\
\hline $\begin{array}{l}\text { Sak and Karymshakov } \\
\text { (2012) }\end{array}$ & 1995-2008 & 135 countries & VECM & GDP & TR & TR increases GDP \\
\hline $\begin{array}{l}\text { Lee and Brahmasrene } \\
\text { (2013) }\end{array}$ & 1988-2009 & European Union countries & OLS & GDP & TOUR, FDI, $\mathrm{CO}_{2}$ & TOUR increases GDP \\
\hline Balcilar et al. (2014) & 1960-2011 & South Africa & VECM & GDP & TR & TR increases GDP \\
\hline Brida et al. (2015) & 1990-2011 & Mercosur & TLGH & GDP & TE, RER & TE increases GDP \\
\hline Mallick et al. (2016) & 1997-2011 & India & ARDL & GDP & TA & TA increases GDP \\
\hline Yazdi et al. (2017) & 1985-2013 & Iran & ARDL & GDP & FDI, TOUR & TOUR increases GDP \\
\hline Selimi et al. (2017) & 1998-2014 & Western Balkan countries & OLS & GDP & TOUR, FDI, EXP, GOV & TOUR increases GDP \\
\hline Jambor and Leitão (2017) & 1995-2014 & $\begin{array}{l}\text { Central and Eastern Euro- } \\
\text { pean countries }\end{array}$ & OLS & GDP & TA, $\mathrm{CO}_{2}$, FDI, TO & TA increases GDP \\
\hline Mohapatra (2018) & 1995-2014 & SAARC counties & FMOLS & GDP & TR & TR reduces GDP \\
\hline Roudi et al. (2019) & 1995-2014 & 10 SIDS countries & ARDL & GDP & TOUR, EC, FDI & TOUR increases GDP \\
\hline Sokhanvar (2019) & 1995-2014 & European countries & VAR & GDP & TOUR, FDI & TOUR increases GDP \\
\hline Antonakakis et al. (2019) & 1995-2014 & 113 countries & VAR & GDP & $\begin{array}{l}\text { TR, DEM, GOVEFF, } \\
\text { POLREG }\end{array}$ & TR increases GDP \\
\hline Akadiri et al. (2020) & 1985-2017 & Turkey & VAR & GDP & TOUR, GPR & TOUR increases GDP \\
\hline Zhang and Zhang (2020) & 2000-2017 & China & VECM & GDP & TOUR, $\mathrm{CO}_{2}, \mathrm{EC}$ & TOUR increases GDP \\
\hline $\begin{array}{l}\text { Balsalobre and Leitão } \\
\text { (2020) }\end{array}$ & 1995-2014 & EU-28 & FMOLS, DOLS & GDP & TOUR, RENW, $\mathrm{CO}_{2}$, TO & TOUR increases GDP \\
\hline Tecel et al. (2020) & 1995-2016 & 14 countries & PMG-ARDL & GDP & TR, FDI, DC & TR increases GDP \\
\hline Hassoun et al. (2020) & 1995-2017 & Algeria & VAR & GDP & ITE & ITE increases GDP \\
\hline Rehman et al. (2020) & 1995-2015 & Pakistan & ARDL & GDP & TOUR & TOUR increases GDP \\
\hline Tu and Zhang (2020) & $2007-2016$ & China & OLS & GDP & TR, URB, FAI, INS & TR increases GDP \\
\hline Su et al. (2021) & 2000-2019 & China & VAR & GDP & TOUR & TOUR increases GDP \\
\hline $\begin{array}{l}\text { Sokhanvar and Jenkins } \\
\text { (2021) }\end{array}$ & 1995-2019 & Estonia & ARDL & GDP & TOUR, FDI & TOUR increases GDP \\
\hline $\begin{array}{l}\text { Adedoyin et al. (2021a, } \\
\mathrm{b}, \text { ) }\end{array}$ & 2002-2017 & 33 countries & GMM & GDP & $\begin{array}{l}\text { TOUR, TO, LAB, GFCF, } \\
\text { IQ }\end{array}$ & TOUR increases GDP \\
\hline Rasool et al. (2021) & 1995-2015 & BRICS & ARDL & GDP & $\mathrm{TR}, \mathrm{FD}$ & TR increases GDP \\
\hline $\begin{array}{l}\text { Balsalobre-Lorente et al. } \\
\text { (2021) }\end{array}$ & 1970-2015 & Spain & NARDL & GDP & AT, RNW, URB, SG & AT increases GDP \\
\hline $\begin{array}{l}\text { Adedoyin et al. (2021a, } \\
\text { b, ) }\end{array}$ & 2002-2017 & $\begin{array}{l}\text { Tourism-dependent } \\
\text { economies }\end{array}$ & GMM & GDP & TA, TO, L, IQ, GFCF & TA increases GDP \\
\hline
\end{tabular}

$T A$ tourist arrivals, $T R$ tourism receipts, TOUSA expresses international tourism earnings, $L$ real effective exchange rate, $E X C$ exchange rate, $R$ tourism receipts, $G C$ government consumption, $I N V$ investment, $T E$ tourism exports, $P E$ public expenditure, $H C$ human capital, TOUR, tourism, $T L G H$ tested using non-parametric tests, $T E$ tourist expenditure, GPR geopolitical risks, $F D I$ foreign direct investment, $E C$ energy consumption, $R E N W$ renewable energy, $T O$ trade openness, $D C$ domestic credit, ITE international tourism expenditures, $L A B$ labor force, $G F C F$ gross fixed capital formation, $I Q$ institutional quality index, $U R B$ urbanization, $F A I$ fixed assets investment level, $I N S$ industrial structure, $D E M$ democracy, GOVEFF government effectiveness, POLREG political regime, EXP export, GOV government expenditure, SAARC South Asian Association for Regional Cooperation, $F D$ financial development, GDCF gross fixed capital formation. 
Table 2 Summary of recent literature on the tourism-environment nexus

\begin{tabular}{|c|c|c|c|c|c|c|}
\hline Author(s) & Period & Countries & Methodologies & $\begin{array}{l}\text { Depend- } \\
\text { ent vari- } \\
\text { able }\end{array}$ & Independent variable & Conclusion \\
\hline $\begin{array}{l}\text { Durbarry and Seet- } \\
\text { anah (2014) }\end{array}$ & 1978-2011 & Mauritius & ARDL & $\mathrm{CO}_{2}$ & TA & TA increases $\mathrm{CO}_{2}$ \\
\hline León et al. (2014) & 1998-2006 & $\begin{array}{l}\text { Developed and less } \\
\text { developed countries }\end{array}$ & GMM & $\mathrm{CO}_{2}$ & TA, POP, GDP, EF & TA increases $\mathrm{CO}_{2}$ \\
\hline Solarin (2014) & $1972-2010$ & Malaysia & ARDL & $\mathrm{CO}_{2}$ & TA, URB, EC, GDP & TA increases $\mathrm{CO}_{2}$ \\
\hline Al-Mulali et al. (2015) & 1995-2009 & $\begin{array}{l}48 \text { top international } \\
\text { tourism destinations }\end{array}$ & VECM & $\mathrm{CO}_{2}$ & TA, GDP, URB, EC & TA increases $\mathrm{CO}_{2}$ \\
\hline Ng et al. (2016) & $1981-2011$ & Malaysia & ARDL & $\mathrm{CO}_{2}$ & TA, GDP, FDI, EC & TA increases $\mathrm{CO}_{2}$ \\
\hline Sharif et al. (2017) & $1972-2013$ & Pakistan & ARDL & $\mathrm{CO}_{2}$ & TA, GDP, FDI & TA increases $\mathrm{CO}_{2}$ \\
\hline Raza et al. (2017) & 1996-2015 & USA & ARDL & $\mathrm{CO}_{2}$ & TA & TA increases $\mathrm{CO}_{2}$ \\
\hline Dogan et al. (2017) & 1995-2010 & OECD countries & DOLS & $\mathrm{CO}_{2}$ & $\begin{array}{l}\text { GDP, GDP }{ }^{2}, \mathrm{EC}, \mathrm{TA}, \\
\text { TO }\end{array}$ & TA increases $\mathrm{CO}_{2}$ \\
\hline Shakouri et al. (2017) & 1995-2013 & Asia-Pacific countries & GMM & $\mathrm{CO}_{2}$ & GDP, $\mathrm{GDP}^{2}, \mathrm{EC}, \mathrm{TA}$ & TA increases $\mathrm{CO}_{2}$ \\
\hline Zaman et al. (2017) & 1995-2013 & $\begin{array}{l}11 \text { transition econo- } \\
\text { mies }\end{array}$ & OLS & $\mathrm{CO}_{2}$ & $\begin{array}{l}\text { URB, GDP, EU, FDI, } \\
\text { TO, TOUREX }\end{array}$ & $\begin{array}{l}\text { TOUREX increases } \\
\mathrm{CO}_{2}\end{array}$ \\
\hline Nepal et al. (2019) & 1975-2014 & Nepal & VECM & $\mathrm{CO}_{2}$ & TA, GDP, K, EU & TA increases $\mathrm{CO}_{2}$ \\
\hline $\begin{array}{l}\text { Satrovic and Muslija } \\
\text { (2019) }\end{array}$ & 1995-2016 & $\begin{array}{l}\text { Top } 10 \text { touristic desti- } \\
\text { nation }\end{array}$ & VAR & $\mathrm{CO}_{2}$ & TR, URB & TR increases $\mathrm{CO}_{2}$ \\
\hline $\begin{array}{l}\text { Eyuboglu and Uzar } \\
\text { (2020) }\end{array}$ & 1960-2014 & Turkey & ARDL & $\mathrm{CO}_{2}$ & TA, EC, GDP & TA increases $\mathrm{CO}_{2}$ \\
\hline Khan et al. (2020) & $1975-2017$ & Pakistan & ARDL & $\mathrm{CO}_{2}$ & TR, GDP, K, EC & TA increases $\mathrm{CO}_{2}$ \\
\hline Kumail et al. (2020) & 1990-2016 & Pakistan & ARDL & $\mathrm{CO}_{2}$ & TI, TR, GDP & TA increases $\mathrm{CO}_{2}$ \\
\hline Kocak et al. (2020) & $1995-2014$ & Most visited countries & GMM, DOLS & $\mathrm{CO}_{2}$ & URB, GDP, TA, EI & TA increases $\mathrm{CO}_{2}$ \\
\hline Setareh et al. (2020) & $1977-2015$ & Cyprus & ARDL & $\mathrm{CO}_{2}$ & $\begin{array}{l}\text { TA, GDP, GDP }{ }^{2}, \text { EC, } \\
\text { RER }\end{array}$ & TA increases $\mathrm{CO}_{2}$ \\
\hline $\begin{array}{l}\text { Jayasinghe and Sel- } \\
\text { vanathan (2021) }\end{array}$ & 1991-2018 & India & ARDL-VECM & $\mathrm{CO}_{2}$ & GDP, EC, TA & TA increases $\mathrm{CO}_{2}$ \\
\hline $\begin{array}{l}\text { Adedoyin et al. } \\
(2021 \mathrm{a}, \mathrm{b},)\end{array}$ & 1995-2018 & EU & GMM & $\mathrm{CO}_{2}$ & GDP, EC, TOUR, ECI & TOUR increases $\mathrm{CO}_{2}$ \\
\hline Gyamfi et al. (2021) & 1995-2018 & G-7 & ARDL & $\mathrm{CO}_{2}$ & GDP, EC, TOUR & TOUR increases $\mathrm{CO}_{2}$ \\
\hline $\begin{array}{l}\text { Lee and Brahmasrene } \\
\text { (2013) }\end{array}$ & 1988-2008 & $\begin{array}{l}\text { European Union } \\
\text { countries }\end{array}$ & OLS & $\mathrm{CO}_{2}$ & TR, GDP, FDI & TR reduces $\mathrm{CO}_{2}$ \\
\hline Jahromi et al. (2017) & 1979-2010 & $\begin{array}{l}5 \text { Southeast Asia } \\
\text { countries }\end{array}$ & ARDL & $\mathrm{CO}_{2}$ & TA, GDP, EC, URB & TA reduces $\mathrm{CO}_{2}$ \\
\hline $\begin{array}{l}\text { Jebli and Hadhri } \\
\text { (2018) }\end{array}$ & 1995-2013 & $\begin{array}{l}\text { Top } 10 \text { international } \\
\text { tourism destinations }\end{array}$ & FMOLS, DOLS & $\mathrm{CO}_{2}$ & TRS, GDP, EU & TRS reduces $\mathrm{CO}_{2}$ \\
\hline Liu et al. (2019) & 1980-2016 & Pakistan & ARDL & $\mathrm{CO}_{2}$ & TR, EC, GDP & $\begin{array}{l}\text { TR have no significant } \\
\text { impact on } \mathrm{CO}_{2}\end{array}$ \\
\hline Jebli et al. (2019) & 1995-2010 & $\begin{array}{l}22 \text { Central and South } \\
\text { American countries }\end{array}$ & FMOLS, DOLS & $\mathrm{CO}_{2}$ & $\begin{array}{l}\text { GDP, TRS, TO, FDI, } \\
\text { RE }\end{array}$ & TRS reduces $\mathrm{CO}_{2}$ \\
\hline Oad et al. (2021) & 1972-2013 & Pakistan & VECM & $\mathrm{CO}_{2}$ & TA, EU, GDP, EXR & $\begin{array}{l}\text { TA have no significant } \\
\text { impact on } \mathrm{CO}_{2}\end{array}$ \\
\hline $\begin{array}{l}\text { Katircioglu et al. } \\
\text { (2018) }\end{array}$ & 1995-2014 & $\begin{array}{l}10 \text { major tourist } \\
\text { countries }\end{array}$ & OLS & $\mathrm{EF}$ & $\mathrm{GDP}, \mathrm{GDP}_{2}, \mathrm{EC}, \mathrm{TR}$ & TR reduces EF \\
\hline $\begin{array}{l}\text { Kongbuamai et al., } \\
\text { 2020a) }\end{array}$ & 1995-2016 & ASEAN & Driscoll-Kraay & $\mathrm{EF}$ & $\begin{array}{l}\text { GDP, GDP } 2, \text { NAT, EC, } \\
\text { TRS }\end{array}$ & TRS reduces EF \\
\hline $\begin{array}{l}\text { Balsalobre-Lorente } \\
\text { et al. (2020) }\end{array}$ & 1994-2014 & OECD & FMOLS & $\mathrm{CO}_{2}$ & $\begin{array}{l}\text { TRS, GDP, GDP }{ }^{2} \text {, } \\
\text { KOF, EU }\end{array}$ & TRS reduces $\mathrm{CO}_{2}$ \\
\hline $\begin{array}{l}\text { Kongbuamai et al. } \\
(2020 \mathrm{a}, \mathrm{b})\end{array}$ & 1974-2016 & Thailand & ARDL & $\mathrm{EF}$ & TA, TO, POP, EC & TA reduces EF \\
\hline Lee and Chen (2021) & 1992-2016 & 123 countries & Quantile regression & $\mathrm{EF}$ & $\mathrm{REV}, \mathrm{GDP}, \mathrm{GDP}_{2}$, & REV reduces EF \\
\hline Khan and Hou (2021) & 1995-2018 & IEA & FMOLS & $\mathrm{EF}$ & TOURISM, EC, K, L & TOURISM reduces EF \\
\hline
\end{tabular}


Table 2 (continued)

\begin{tabular}{|c|c|c|c|c|c|c|}
\hline Author(s) & Period & Countries & Methodologies & $\begin{array}{l}\text { Depend- } \\
\text { ent vari- } \\
\text { able }\end{array}$ & Independent variable & Conclusion \\
\hline Godil et al. (2020) & 1986-2018 & Turkey & Q-ARDL & $\mathrm{EF}$ & GLOB, FD, TOUR & TOUR increases EF \\
\hline Nathaniel et al. (2021) & 1995-1016 & $\begin{array}{l}\text { Top } 10 \text { tourist destina- } \\
\text { tions }\end{array}$ & FMOLS & $\mathrm{EF}$ & $\begin{array}{l}\text { URB, GDP, TOUR, } \\
\text { EI, NAT }\end{array}$ & TOUR increases EF \\
\hline
\end{tabular}

$T A$ tourist arrival, $U R B$ urbanization, $E C$ energy consumption, $T O$ trade openness, $T E$ tourist expenditure, $P O P$ total population, $T R$ tourism receipts, $F D I$ foreign direct investment, $K$ capital, $T I$ technological innovation, $E U$ energy use, $E X R$ exchange rate, $E I$ energy intensive, $E F$ energy efficiency, TRS international tourism, TOUREX tourism expenditure, $R E$ renewable energy consumption, $E F$ ecological footprint, $N A T$ natural resources, $Q-A R D L$ quantile autoregressive distributed lag, $F D$ financial development, $G L O B$ globalization, $R E V$ international tourism revenues, IEA International Energy Agency countries, TOURISM tourism growth, $L$ labor, KOF globalization index, ECI economic complexity index.

is a form of development that includes environmental effects, the STIRPAT model, which is used to observe the effects of a factor on the environment, is used in the study. This model is based on the IPAT model developed by Ehrlich and Holdren (1971), which describes environmental impacts (I), population $(\mathrm{P})$, affluence (A), and technology (T). While the environmental impact of each factor is calculated proportionally in the IPAT model, York et al. (2003) revised the IPAT model and developed the STIRPAT model, which is a stochastic version of IPAT model. The STIRPAT model and the logarithmic form of the model are as follows, respectively:

$I_{i t}=a P_{i t}^{b} A_{i t}^{c} T_{i t}^{d} u_{i t}$

$\ln I_{i t}=a_{i}+b \ln P_{i t}+c \ln A_{i t}+d \ln T_{i t}+u_{i t}$

where the coefficients of $b, c$, and $d$ indicate the impact of population, affluence, and technology, respectively. Following Zhang et al. (2017) and Kocak et al. (2020), we used tourism as an affluence variable. In addition, similar to previous studies, we used two widely used indicator (tourist arrivals and tourism receipts) as an indicator of tourism development. However, unlike previous studies, we used sustainable development as an environmental indicator and final empirical models are constructed as follows:

$$
\begin{aligned}
& s d_{i t}=a_{1}+b_{1} u r b_{i t}+c_{1} \operatorname{tar}_{i t}+d_{1} e i_{i t}+u_{1 i t} \\
& s d_{i t}=a_{2}+b_{2} u r b_{i t}+c_{2} \operatorname{trec}_{i t}+d_{2} e i_{i t}+u_{2 i t}
\end{aligned}
$$

where $s d, u r b$, tar, trec, and $e i$ represent sustainable development, urbanization, number of tourist arrivals, tourism receipts, and energy intensity, respectively. In addition, to separate the relative impacts of tourism on sustainable development and economic growth, we also establish two more empirical models as follows:

$g d p_{i t}=a_{3}+b_{3} u r b_{i t}+c_{3} \operatorname{tar}_{i t}+d_{3} e i_{i t}+u_{3 i t}$ $g d p_{i t}=a_{4}+b_{4} u r b_{i t}+c_{4} t_{a r}+d_{4} e i_{i t}+u_{4 i t}$

where $g d p$ stands for economic growth. In empirical procedure of this study, the Eq. (3) and Eq. (4) are called as model 1 and model 2, respectively. For economic growth function, Eq. (5) and Eq. (6) are called as model 3 and model 4 , respectively.

In the empirical analysis, annual data covering the period 1995-2015 for the 10 most visited countries (China, France, Germany, Italy, Mexico, Spain, Thailand, Turkey, UK, and USA) are used. The use of the dataset until 2015 is due to the availability of energy intensity and tourism data until 2015. While creating the datasets, sustainable development index representing sustainable development, real GDP per capita in constant 2010 US dollar representing economic growth, urban population share in total population representing urbanization, the number of tourist arrivals and international tourism receipts share in total exports representing the tourism development, and energy intensity level of primary energy representing energy intensity. Sustainable development index data is used from the dataset developed by Hickel (2020). In addition, the tourism data is obtained from (UNWTO, 2015). The other data are used from the World Development Indicators of World Bank database. All variables are handled in logarithmic form.

\section{Methodology}

\section{Preliminary analysis}

When working with panel data, choosing the correct estimator is critical for getting clear and reliable results for policy recommendations. Since the global financial crisis of 2008 had an impact on practically every country, it is expected that estimators (also known as first-generation estimators) that do not account for inter-country reliance may provide inaccurate results. As a result, it is virtually probably necessary to evaluate cross-sectional reliance between countries using panel data methodologies (hereafter, CSD). In 
this study, the LM of Breusch and Pagan (1980), the $\mathrm{CD}_{\mathrm{LM}}$ and CD of Pesaran (2004), and the LMadj of Pesaran et al. (2008) are used to investigate the CSD problem. The stationarity process, which is crucial in all econometric forecasts, should also be taken into account. As a result, we use Pesaran's (2007) CIPS unit root test, which allows for CSD in our study. At the conclusion of the preliminary testing, the validity of the long-term relationship between the variables is tested, and this has an impact on the estimator chosen. As a result, Westerlund (2008) uses the DH (Durbin-Hausman) cointegration test to assess the validity of the stated connection.

\section{Estimation for long-run parameters}

After confirming cross-sectional dependent cointegration among variables, the coefficient of cointegrated regressor should be searched using an estimation technique that enables cross-sectional dependence. As a result, we use Bai et al.'s (2009) CUP-FM (constantly updated and fully modified) and CUP-BC (constantly updated and bias-corrected) models. These estimators, which assume cross-sectional dependency and an error term (e.g., Bai and Kao, 2006), make the following contributions to the fundamental panel regression model:

$y_{i t}=a_{i}+\beta x_{i t}+\varepsilon_{i t}$

$\varepsilon_{i t}=\lambda_{i}^{\prime} F_{t}+\mu_{i t}$

where $F_{t}, \lambda_{i}^{\prime}$, and $\mu_{i t}$ denote the vector of common factors, the corresponding factor loadings, and the error term's idiosyncratic variable, respectively. The CUP-FM computation procedure is based on estimating coefficients and the long-run co-variance matrix repeatedly before convergence is achieved as follows:
Finally, both estimators are resilient in the presence of endogeneity (Bai et al., 2009).

\section{Empirical findings}

\section{The results of preliminary analyses}

The issue of cross-section dependence has become increasingly important in recent years in panel data investigations. As a result, the employment of second-generation cross-section dependence methods, rather than first-generation panel data methods, which are based on the premise that there is no cross-section dependency, is becoming more common. The inter-country reliance for the two key variables examined in this study is similarly high. Climate change is caused by a country's production structure based on extremely intense emission-emitting fossil fuels, which has an impact on all countries' sustainable development goals. One of the areas where inter-country reliance is high is tourism. It is well known that when a terrorist incident occurs in one of the countries that has received a large number of tourists in the past, the countries that are touristic rivals benefit from the scenario. During the current COVID-19 outbreak, it became clear how interdependent the countries are in the tourism sector. As a result, cross-section dependency tests are employed in the first step of the empirical analysis to examine the reliance between nations for the variables under discussion, and the results are provided in Table 3. The null hypothesis that there is no CSD among nations for all variables is severely rejected by the CSD test findings in Table 3 . This means that a change in the factors studied in any of the ten countries studied has an impact on the others.

Numbers in brackets are $p$ values.

The usage of second-generation panel data methodologies is required for the validity of CSD. As a result, while

$\widehat{\beta}_{\text {Cup }}=\left[\sum_{i=1}^{n}\left(\sum_{t=1}^{T} \hat{y}_{i t}^{+}\left(\hat{\beta}_{\text {Cup }}\right)\left(x_{i t}-\bar{x}_{i}\right)^{\prime}-T\left(\left(\lambda_{i}^{\prime}\left(\widehat{\beta}_{\text {Cup }}\right) \widehat{\Delta}_{F \varepsilon i}^{+}\left(\hat{\beta}_{\text {Cup }}\right)+\widehat{\Delta}_{\mu \varepsilon i}^{+}\left(\hat{\beta}_{\text {Cup }}\right)\right)\right)\right] \times\left[\sum_{i=1}^{n} \sum_{t=1}^{T}\left(x_{i, t}-\bar{x}_{i}\right)\left(x_{i, t}-\bar{x}_{i}\right)^{\prime}\right]^{-1}\right.$

where $\hat{y}_{i t}^{+}=y_{i t}-\left(\hat{\lambda}_{i}^{\prime} \hat{\Omega}_{F \varepsilon i}+\widehat{\Omega}_{\mu \varepsilon i}\right) \hat{\Omega}_{\varepsilon i}^{-1} \Delta x_{i t}, \hat{\Omega}_{F \varepsilon i}$ and $\widehat{\Omega}_{\mu \varepsilon i}$ are estimated long-run co-variance matrices and $\hat{\Delta}_{F \varepsilon i}^{+}$and $\widehat{\Omega}_{\mu \varepsilon i}$ are estimated one-sided long-run co-variance.

For a variety of reasons, the CUP-FM and CUP-BC estimators were also used in this study. These estimators, for example, are consistent tests in the case of exogenous explanatory variables, similar to the cointegration test we chose. These estimators can also be used to mix variables in different orders. Furthermore, because the CUP-FM estimator is based on a fully modified OLS estimator that uses the Bartlett-Kernel method, it can be used in autocorrelation and heteroskedasticity scenarios (Kiefer and Vogelsang, 2002). analyzing the stationarity processes of variables, unit root tests that allow CSD should be utilized. The CIPS panel unit root test is performed to determine the stationarity of the variables in this direction, and the results are shown in Table 4 . The null hypothesis that the series includes a unit root for the level values of all the variables is not rejected based on the test results. In the first difference form of all variables, on the other hand, the null hypothesis is rejected, and the series is stationary.

Because the variables are stationary at their first difference, they are integrated in the first order. This enables a cointegrated relationship between the variables to be 
Table 3 Cross-sectional dependence test results

\begin{tabular}{lllll}
\hline & LM & CD $_{\text {LM }}$ & LMadj & CD \\
\hline$s d$ & 87.023 & 3.053 & -2.872 & 2.831 \\
& {$[0.004]$} & {$[0.001]$} & {$[0.002]$} & {$[0.002]$} \\
gdp & 51.168 & 3.096 & -1.535 & 6.331 \\
& {$[0.005]$} & {$[0.001]$} & {$[0.062]$} & {$[0.000]$} \\
\multirow{4}{*}{ urb } & 96.508 & 3.958 & -2.305 & 8.123 \\
& {$[0.000]$} & {$[0.000]$} & {$[0.011]$} & {$[0.000]$} \\
\multirow{2}{*}{ i } & 88.480 & 3.192 & -2.757 & 3.265 \\
& {$[0.003]$} & {$[0.001]$} & {$[0.003]$} & {$[0.001]$} \\
\multirow{2}{*}{ tar } & 94.019 & 3.720 & -2.725 & 4.962 \\
& {$[0.001]$} & {$[0.000]$} & {$[0.003]$} & {$[0.000]$} \\
\multirow{2}{*}{ trec } & 86.824 & 3.034 & -2.637 & 4.322 \\
& {$[0.004]$} & {$[0.001]$} & {$[0.004]$} & {$[0.000]$} \\
\hline
\end{tabular}

Numbers in brackets are $p$ values.

investigated. As a result, the $\mathrm{DH}$ cointegration test is used to assess the validity of the cointegration relationship for the four different targeted models, with the results displayed in Table 5. According to the findings, the variables are cointegrated, in other words, there is a legitimate long-term link between the variables for all models based on DH-Group and DH-Panel statistics.

\section{The results of long-run parameters}

The CUP-FM and CUP-BC cointegrated coefficient estimators are then used to look at the long-term impacts of the independent variables on the dependent variable for the models that have been determined to have valid longterm associations. First, the effects of urbanization, energy intensity, and tourism development on sustainable development are explored, and the results are presented in Table 6. When the findings are analyzed in the context of model I, it becomes clear that urbanization hinders and limits sustainable development. Despite the fact that no study specifically evaluates the influence of urbanization on sustainable development, our findings are consistent with the findings of Solarin (2014), Al-Mulali et al. (2015), and Satrovic and Muslija (2019) that revealed urbanization had a negative impact on environmental quality. Similarly, it has been determined that high energy intensity is detrimental to longterm development. When viewed in terms of environmental consequences, this finding is consistent with the findings of
Table 5 Cointegration test results

\begin{tabular}{lllll}
\hline & Model I & Model II & Model III & Model IV \\
\hline DH_Group & 2.266 & 1.577 & 3.637 & 3.047 \\
& {$[0.012]$} & {$[0.057]$} & {$[0.000]$} & {$[0.001]$} \\
DH_Panel & 4.195 & 1.645 & 3.132 & 12.355 \\
& {$[0.000]$} & {$[0.050]$} & {$[0.001]$} & {$[0.000]$} \\
\hline
\end{tabular}

Table 6 Long-run impacts of tourism on sustainable development

\begin{tabular}{|c|c|c|c|c|}
\hline & \multicolumn{2}{|l|}{ CUP-FM } & \multicolumn{2}{|l|}{ CUP-BC } \\
\hline & Coefficient & $t$-Statistics & Coefficient & $t$-Statistics \\
\hline \multicolumn{5}{|c|}{ Model I } \\
\hline$u r b$ & $-0.012 * * *$ & -6.205 & $-0.011 * * *$ & -7.119 \\
\hline$e i$ & $-0.008 * * *$ & -3.069 & $-0.007 * * *$ & -3.098 \\
\hline tar & $-0.002 * * *$ & -6.395 & $-0.003 * * *$ & -7.684 \\
\hline \multicolumn{5}{|c|}{ Model II } \\
\hline$u r b$ & $-0.012 * * *$ & -7.651 & $-0.011 * * *$ & -7.903 \\
\hline$e i$ & $-0.007 * * *$ & -9.111 & $-0.007 * * *$ & -9.701 \\
\hline trec & $-0.001 *$ & -1.656 & $-0.001 * * *$ & -5.125 \\
\hline
\end{tabular}

$*, * *$, and $* * *$ indicate the statistical significance at 10,5 , and $1 \%$ level, respectively.

Kocak et al. (2020) and Nathaniel et al. (2021). Finally, it has been discovered that an increase in the number of tourists has a negative impact on sustainable development. This outcome is analogous to what was reported in Durbarry and Seetanah (2014), Ng et al. (2016), Raza et al. (2017), Khan et al. (2020), and Jeyasinghe and Selvanathan (2021).

When the analysis results in Table 6 are reviewed in the context of model II, it is clear that model I yields similar results. In particular, it is shown that increased urbanization, energy intensity, and tourism revenues diminish the sustainable development index, i.e., they impair sustainability. The conclusion that increased tourism revenue has a negative impact on environmental quality is consistent with Satovic and Muslija (2019), Godil et al. (2020), and Nathaniel et al. (2021).

The impact of tourism on economic growth is also explored, and the results are reported in Table 7 . According to the findings, urbanization leads to economic growth in both the model III and model IV frameworks. This finding is consistent with the findings of Chen et al. (2014),

Table 4 Unit root test results

\begin{tabular}{lllllll}
\hline & $s d$ & $g d p$ & $u r b$ & ei & tar & trec \\
\hline Level & -2.143 & -2.290 & -0.818 & -1.457 & -1.787 & -1.308 \\
First differences & $-3.514^{* * *}$ & $-3.271^{* *}$ & $-3.366^{* *}$ & $-4.732^{* * *}$ & $-4.131^{* * *}$ & $-4.478^{* * *}$ \\
\hline
\end{tabular}

Critical values for 10,5 , and $1 \%$ level are $-2.82,-3.02,-3.46$, respectively. *, **, and *** indicate the statistical significance at 10,5 , and $1 \%$ level, respectively. 
Bakirtas and Akpolat (2018), and Tu and Zhang (2020). The conclusion is that increasing energy intensity also boosts real GDP, which is consistent with Sinha (2016), Diaz et al. (2019), and Mahmood et al. (2021). The impact of tourism on economic growth is measured independently in terms of the number of visitors and the amount of money spent on tourism. According to the findings, an increase in the number of tourists has a beneficial impact on economic growth. When comparing the results of earlier investigations, we can observe that this one is consistent with Jambor and Leitao (2017) and Mallick et al. (2016). Furthermore, our findings that increased tourism revenues lead to economic growth are consistent with the findings of Balcilar et al. (2014), Selimi et al. (2017), and Antonakakis et al. (2019).

\section{Discussions}

We expected to find that urbanization and energy intensity both contribute to economic growth. In fact, for countries that prioritize economic prosperity, the expansion of the industrial sector is reliant on high energy consumption, while the development of the service sector is reliant on migration from rural to urban areas. Similarly, it is unsurprising that tourism development has a favorable impact on economic growth. Even tourism's foreign exchange inflow and employment-increasing impacts contribute to a country's economic prosperity. The findings in our empirical model, which show that all factors that promote economic growth are detrimental to sustainable development, are surprising. It is worth noting that the index for sustainable development also considers economic growth. That is, economic growthrelated issues harm an index that also incorporates economic growth. This damage suggests that these elements cause more harm to social and environmental aspects than they give in terms of economic progress. The fact that countries' energy portfolios are primarily made up of fossil resources

Table 7 Long-run impacts of tourism on economic growth

\begin{tabular}{|c|c|c|c|c|}
\hline & \multicolumn{2}{|l|}{ CUP-FM } & \multicolumn{2}{|l|}{ CUP-BC } \\
\hline & Coefficient & $t$-Statistics & Coefficient & $t$-Statistics \\
\hline \multicolumn{5}{|c|}{ Model III } \\
\hline$u r b$ & $0.085 * * *$ & 7.037 & $0.071 * * *$ & 4.034 \\
\hline$e i$ & $0.035 * * *$ & 3.545 & $0.050 * * *$ & 4.925 \\
\hline tar & $0.062 * * *$ & 9.827 & $0.068 * * *$ & 2.725 \\
\hline \multicolumn{5}{|c|}{ Model IV } \\
\hline$u r b$ & $0.087 * * *$ & 7.092 & $0.070 * * *$ & 3.538 \\
\hline$e i$ & $0.039 * * *$ & 11.480 & $0.054 * * *$ & 5.983 \\
\hline trec & $0.061 * * *$ & 9.182 & $0.067 * * *$ & 2.768 \\
\hline
\end{tabular}

$*$, ** and *** indicate the statistical significance at 10,5 and $1 \%$ level, respectively. contributes to the harm caused by increased energy intensity to sustainable development. Furthermore, the harm caused by urbanization to sustainable development is due to the fact that the rise in migration from rural to urban regions occurs without a proper urbanization policy in place. Other reasons of the damage include changes in the consumption patterns of people who adapt to city life as a result of urbanization and the increase in population density.

While the development of tourism contributes to economic growth, harming sustainable development is largely related to the damage caused by tourism activities to the environment. Moreover, according to the findings, the damage caused by tourism to environmental quality is more than its contribution to economic growth. Tourism can harm the environment in various ways as follows: (i) excessive consumption in touristic facilities, (ii) destruction of forest areas due to the establishment of tourist facilities on forest lands, (iii) soil erosion due to destruction of forest lands, (iv) forest fires originating from facilities close to forest lands, (v) the intensive energy consumption of the facilities and the supply of this energy to a large extent from fossil sources, (vi) marine pollution due to the waste problems of the facilities in the coastal areas, (vii) the inability of the transportation vehicles carrying passengers to the facilities to operate at full capacity, and (viii) the inadequacy of the facility managers in environmental awareness and training.

\section{Conclusions}

The effects of tourism on sustainable development are examined in this study by combining them with the effects of urbanization and energy intensity. While doing so, two different measures, the number of tourists and tourism profits, are used to reflect tourism development. The period 1995-2015 is examined in this direction using secondgeneration panel data methodologies that allow for intercountry dependency. In addition, a second empirical model is constructed to compare the effects of tourism on sustainable development with the effects of tourism on economic growth, as well as the influence of the same independent variables on economic growth.

The results of the empirical investigations can be summarized as follows: (i) urbanization is detrimental to sustainable development; (ii) increased energy intensity is detrimental to sustainable development; (iii) tourism development is detrimental to sustainable development; (iv) urbanization is beneficial to economic growth; (v) increased energy intensity is beneficial to growth; and (vi) tourism development is beneficial to economic growth. When these findings are compared in binary form, findings $i$ and iv show that urbanization, while beneficial to economic growth, is detrimental to sustainable development. 
In other words, positive economic growth as a result of urbanization does not compensate for the environmental damage caused by urbanization. Similarly, findings ii and $v$ reveal that increasing energy intensity, which contributes to economic growth, has a greater negative impact on environmental indicators than it has a positive impact on economic growth. Finally, conclusions iii and vi show that the harm caused by the tourism sector, which is a key foreign exchange input instrument for countries, outweighs the economic gains it delivers.

When considering the impact of tourism on sustainable development, it is worth noting that even the most visited countries are unable to accomplish sustainable tourism transformation. The following policies can be suggested in the context of policy proposals: (i) tourist facilities should be required to produce a portion of the energy portfolio they consume from renewable sources; (ii) transportation vehicles providing transportation services to touristic facilities should be required to operate at full capacity; (iii) waste separation and recycling processes should be made mandatory in these facilities; (iv) the use of recyclable materials in textile items used in these facilities should be made mandatory; (v) staff working in touristic facilities should be informed on the dimensions of tourism-induced climate change; (vi) countries with high tourism income should direct some of their income from tourism to tourist education in order to protect environmental quality; (vii) policy makers aiming to increase tourist demand need to establish a balance between the cost of environmental investments and tourist revenues; (viii) in addition, companies operating in the tourism sector in the most visited countries can be encouraged by governments to the extent that they reduce carbon emissions; (ix) due to the COVID epidemic, there will undoubtedly be a change in travel and tourism activities in the world, decision units need to consider sustainable consumption channels in the tourism sector for sustainable tourism in the post-COVID period; and (x) finally, policy makers should increase investments in low-carbon technology and actively promote its implementation.

There are some limitations in this study. For example, the methods used in the study observe the symmetrical relationship between tourism and the environment. Observing the asymmetrical relationship between the variables in future studies will give a chance to more detailed recommendations in the context of policy recommendations. In addition, the assumption of a linear relationship between the variables is valid. The use of methods based on the assumption of non-linear relationship in future studies may lead to new ideas in the literature.

Author contribution Mehmet Akif Destek: data curation, resources, methodology, investigation, formal analysis, writing original draft, review and editing; Sercan Aydin: writing original draft, writingreview and editing.

Data availability Not applicable.

\section{Declarations}

Ethics approval This article does not contain any studies with human participants performed by any of the authors.

Consent to participate No human or animal subjects were used in our study, and no questionnaire was conducted.

Consent for publication Our study does not contain individual person's data.

Competing interests The authors declare no competing interests.

\section{References}

Adedoyin, F. F., Erum, N., \& Bekun, F. V. (2021). How does institutional quality moderates the impact of tourism on economic growth? Startling evidence from high earners and tourismdependent economies. Tourism Economics, 1354816621993627.

Adedoyin FF, Agboola PO, Ozturk I, Bekun FV, Agboola MO (2021) Environmental consequences of economic complexities in the EU amidst a booming tourism industry: accounting for the role of brexit and other crisis events. Journal of Cleaner Production 305:127117

Al-Mulali U, Fereidouni HG, Mohammed AH (2015) The effect of tourism arrival on $\mathrm{CO} 2$ emissions from transportation sector. Anatolia 26(2):230-243

Antonakakis N, Dragouni M, Eeckels B, Filis G (2019) The tourism and economic growth enigma: examining an ambiguous relationship through multiple prisms. J Travel Res 58(1):3-24

Azam M, Alam MM, Hafeez MH (2018) Effect of tourism on environmental pollution: further evidence from Malaysia, Singapore and Thailand. J Clean Prod 190:330-338

Balsalobre-Lorente D, Driha OM, Shahbaz M, Sinha A (2020) The effects of tourism and globalization over environmental degradation in developed countries. Environ Sci Pollut Res 27(7):7130-7144

Balaguer J, Cantavella-Jorda M (2002) Tourism as a long-run economic growth factor: the Spanish case. Appl Econ 34(7):877-884

Balcilar M, Van Eyden R, Inglesi-Lotz R, Gupta R (2014) Time-varying linkages between tourism receipts and economic growth in South Africa. Appl Econ 46(36):4381-4398

Balsalobre-Lorente D, Leitão NC (2020) The role of tourism, trade, renewable energy use and carbon dioxide emissions on economic growth: evidence of tourism-led growth hypothesis in EU-28. Environ Sci Pollut Res 27(36):45883-45896

Balsalobre-Lorente D, Driha OM, Bekun FV, Adedoyin FF (2021) The asymmetric impact of air transport on economic growth in Spain: fresh evidence from the tourism-led growth hypothesis. Curr Issue Tour 24(4):503-519

Başarir Ç, Çakir YN (2015) Causal interactions between CO2 emissions, financial development, energy and tourism. Asian Economic and Financial Review 5(11):1227-1238

Ben Jebli M, Hadhri W (2018) The dynamic causal links between CO2 emissions from transport, real GDP, energy use and international tourism. Int J Sust Dev World 25(6):568-577 
Bilen M, Yilanci V, Eryüzlü H (2017) Tourism development and economic growth: a panel Granger causality analysis in the frequency domain. Curr Issue Tour 20(1):27-32

Brida JG, Lanzilotta B, Pereyra JS, Pizzolon F (2015) A nonlinear approach to the tourism-led growth hypothesis: the case of the MERCOSUR. Curr Issue Tour 18(7):647-666

Chen M, Zhang H, Liu W, Zhang W (2014) The global pattern of urbanization and economic growth: evidence from the last three decades. PloS one 9(8):e103799

Bakirtas T, Akpolat AG (2018) The relationship between energy consumption, urbanization, and economic growth in new emergingmarket countries. Energy 147:110-121

Sinha A (2016) Trilateral association between SO2/NO2 emission, inequality in energy intensity, and economic growth: a case of Indian cities. Atmos Pollut Res 7(4):647-658

Díaz A, Marrero GA, Puch LA, Rodríguez J (2019) Economic growth, energy intensity and the energy mix. Energy Economics 81:1056-1077

Mahmood T, Ullah S, Mumtaz M (2021) Dependence of energy intensity on economic growth: panel data analysis of South Asian economies. International Journal of Energy Economics and Policy 11(2):234

Cárdenas-García PJ, Sánchez-Rivero M, PulidoFernández JI (2013) Does tourism growth influence economic development? Journal of Travel Research XX $(\mathrm{X}): 1-16$

Chen CF, Chiou-Wei SZ (2009) Tourism expansion, tourism uncertainty and economic growth: new evidence from Taiwan and Korea. Tour Manage 30(6):812-818

Dogan E, Seker F, Bulbul S (2017) Investigating the impacts of energy consumption, real GDP, tourism and trade on $\mathrm{CO} 2$ emissions by accounting for cross-sectional dependence: a panel study of OECD countries. Curr Issue Tour 20(16):1701-1719

Dritsakis N (2004) Tourism as a long-run economic growth factor: an empirical investigation for Greece using causality analysis. Tour Econ 10(3):305-316

Dritsakis N (2012) Tourism development and economic growth in seven Mediterranean countries: a panel data approach. Tour Econ 18(4):801-816

Du D, Lew AA, Ng PT (2016) Tourism and economic growth. J Travel Res 55(4):454-464. https://doi.org/10.1177/0047287514563167

Durbarry R (2002) The economic contribution of tourism in Mauritius. Ann Tour Res 29(3):862-865

Durbarry R (2004) Tourism and economic growth: the case of Mauritius. Tour Econ 10(4):389-401

Durbarry R, Seetanah B (2014) Assessing the impact of tourism and travel on climate change. J Hosp Market Manag 24(4):401-410

Eugenio-Martin, J. L., N. M. Morales, and R. Scarpa. (2004). "Tourism and economic growth in Latin American countries: a panel data approach." FEEM working paper no. 26, Social Science Research Network. http://ssrn.com/abstract $=504482$ (accessed October 27, 2012)

Eyuboglu K, Uzar U (2020) The impact of tourism on CO2 emission in Turkey. Curr Issue Tour 23(13):1631-1645

Farajırad, A., \& Aghajanı, S. (2010). The relationship between tourism and environment

Godil DI, Sharif A, Rafique S, Jermsittiparsert K (2020) The asymmetric effect of tourism, financial development, and globalization on ecological footprint in Turkey. Environ Sci Pollut Res 27(32):40109-40120

Gunduz L, Hatemi-J A (2005) Is the tourism-led growth hypothesis valid for Turkey? Appl Econ Lett 12:499-504

Gyamfi, B. A., Bein, M. A., Adedoyin, F. F., \& Bekun, F. V. (2021). To what extent are pollutant emission intensified by international tourist arrivals? Starling evidence from G7 countries. Environment, Development and Sustainability, 1-22.
Habibi F, Rahmati M, Karimi A (2018) Contribution of tourism to economic growth in Iran's provinces: GDM approach. Future Business Journal 4(2):261-271

Hassoun SES, Adda KS, Sebbane AH (2021) Examining the connection among national tourism expenditure and economic growth in Algeria. Future Business Journal 7(1):1-9

Hunter C, Green H (1995) Tourism and the environment: a sustainable relationship? Routledge

Jayasinghe M, Selvanathan EA (2021) Energy consumption, tourism, economic growth and $\mathrm{CO} 2$ emissions nexus in India. Journal of the Asia Pacific Economy 26(2):361-380

Jebli MB, Youssef SB, Apergis N (2015) The dynamic interaction between combustible renewables and waste consumption and international tourism: the case of Tunisia. Environ Sci Pollut Res 22(16):12050-12061

Jebli MB, Youssef SB, Apergis N (2019) The dynamic linkage between renewable energy, tourism, $\mathrm{CO} 2$ emissions, economic growth, foreign direct investment, and trade. Latin American Economic Review 28(1):1-19

Katircioglu S, Gokmenoglu KK, Eren BM (2018) Testing the role of tourism development in ecological footprint quality: evidence from top 10 tourist destinations. Environ Sci Pollut Res 25(33):33611-33619

Khan A, Bibi S, Ardito L, Lyu J, Hayat H, Arif AM (2020) Revisiting the dynamics of tourism, economic growth, and environmental pollutants in the emerging economies-sustainable tourism policy implications. Sustainability 12(6):2533

Khan I, Hou F (2021) The dynamic links among energy consumption, tourism growth, and the ecological footprint: the role of environmental quality in 38 IEA countries. Environ Sci Pollut Res 28(5):5049-5062

Kim HJ, Chen MH, Jang SC (2006) Tourism expansion and economic development: the case of Taiwan. Tour Manage 27:925-993

Koçak E, Ulucak R, Ulucak ZŞ (2020) The impact of tourism developments on $\mathrm{CO} 2$ emissions: an advanced panel data estimation. Tourism Management Perspectives 33:100611

Kongbuamai N, Bui Q, Yousaf HMAU, Liu Y (2020) The impact of tourism and natural resources on the ecological footprint: a case study of ASEAN countries. Environ Sci Pollut Res 27(16):19251-19264

Kongbuamai N, Zafar MW, Zaidi SAH, Liu Y (2020) Determinants of the ecological footprint in Thailand: the influences of tourism, trade openness, and population density. Environ Sci Pollut Res 27(32):40171-40186

Kumail T, Ali W, Sadiq F, Wu D, Aburumman A (2020) Dynamic linkages between tourism, technology and $\mathrm{CO} 2$ emissions in Pakistan. Anatolia 31(3):436-448

Lee CC, Chen MP (2021) Ecological footprint tourism development and country risk: international evidence. Journal of Cleaner Production 279:123671

Lee CC, Chang CP (2008) Tourism development and economic growth: a closer look at panels. Tour Manage 29:180-192

Lee JW, Brahmasrene T (2013) Investigating the influence of tourism on economic growth and carbon emissions: evidence from panel analysis of the European Union. Tour Manage 38:69-76

Lenzen M, Sun YY, Faturay F, Ting YP, Geschke A, Malik A (2018) The carbon footprint of global tourism. Nat Clim Chang 8(6):522-528

León CJ, Arana JE, Hernández Alemán A (2014) CO2 emissions and tourism in developed and less developed countries. Appl Econ Lett 21(16):1169-1173

Liu, Y., Kumail, T., Ali, W., \& Sadiq, F. (2019). The dynamic relationship between $\mathrm{CO} 2$ emission, international tourism and energy consumption in Pakistan: a cointegration approach. Tourism Review. 
Mallick, L., Mallesh, U., \& Behera, J. (2016). Does tourism affect economic growth in Indian states? Evidence from panel ARDL model. Theoretical \& Applied Economics, 23(1).

Manzoor F, Wei L, Asif M (2019) The contribution of sustainable tourism to economic growth and employment in Pakistan. Int $\mathbf{J}$ Environ Res Public Health 16(19):3785

Massidda C, Mattana P (2013) A SVECM analysis of the relationship between international tourism arrivals, GDP and trade in Italy. J Travel Res 52:93-105

Mohapatra S (2018) Investigating the tourism and economic growth linkage: a panel causality analysis for the SAARC countries. Asia Pacific Journal of Tourism Research 23(6):573-583

Narayan PK, Narayan S, Prasad A, Prasad BC (2010) Tourism and economic growth: a panel data analysis for Pacific Island countries. Tour Econ 16(1):169-183

Nathaniel, S. P., Barua, S., \& Ahmed, Z. (2021). What drives ecological footprint in top ten tourist destinations? Evidence from advanced panel techniques. Environmental Science and Pollution Research, 1-10.

Nepal R, Al Irsyad MI, Nepal SK (2019) Tourist arrivals, energy consumption and pollutant emissions in a developing economyimplications for sustainable tourism. Tour Manage 72:145-154

$\mathrm{Ng}$ TH, Lye CT, Lim YS (2016) A decomposition analysis of CO2 emissions: evidence from Malaysia's tourism industry. Int J Sust Dev World 23(3):266-277

Nissan E, Galindo MA, Méndez MT (2011) Relationship between tourism and economic growth. Serv Ind J 31(10):1567-1572

Oad, S., Jinliang, Q., \& Shah, S. B. H. (2021). Tourism: economic development without increasing $\mathrm{CO} 2$ emissions in Pakistan. Environment, Development and Sustainability, 1-24.

Ongan S, Demiroz DM (2005) "The contribution of tourism to the long-run Turkish economic growth" Ekonomicky Casopis. J Econ 53:880-894

Rasool, H., Maqbool, S., \& Tarique, M. (2021). The relationship between tourism and economic growth among BRICS countries: a panel cointegration analysis. Future Business Journal, 7(1)

Sharif A, Afshan S, Nisha N (2017) Impact of tourism on CO2 emission: evidence from Pakistan. Asia Pacific Journal of Tourism Research 22(4):408-421

Raza SA, Sharif A, Wong WK, Karim MZA (2017) Tourism development and environmental degradation in the United States: evidence from wavelet-based analysis. Curr Issue Tour 20(16): 1768-1790

Rehman A, Ma H, Irfan M, Ahmad M, Traore O (2020) Investigating the influence of international tourism in Pakistan and its linkage to economic growth: evidence from ARDL approach. SAGE Open 10(2):2158244020932525

Roudi S, Arasli H, Akadiri SS (2019) New insights into an old issueexamining the influence of tourism on economic growth: evidence from selected small island developing states. Curr Issue Tour 22(11):1280-1300

Saint Akadiri S, Eluwole KK, Akadiri AC, Avci T (2020) Does causality between geopolitical risk, tourism and economic growth matter? Evidence from Turkey. J Hosp Tour Manag 43:273-277

Sak N, Karymshakov K (2012) Relationship between tourism and economic growth: a panel Granger causality approach. Asian economic and financial review 2(5):591

Setareh K, Najia S, Salih K, Kilinc CC, Hasan G (2020) Estimating the effects of tourism growth on emission pollutants: empirical evidence from a small island, Cyprus. Air Qual Atmos Health 13(4):391-397

Satrovic E, Muslija A (2019) The empirical evidence on tourismurbanization- $\mathrm{CO} 2$ emissions nexus. Advances in Hospitality and Tourism Research (AHTR) 7(1):85-105

Scott D, Gössling S, Hall CM, Peeters P (2016) Can tourism be part of the decarbonized global economy? The costs and risks of alternate carbon reduction policy pathways. J Sustain Tour 24(1):52-72

Selimi, N., Sadiku, M., \& Sadiku, L. (2017). The impact of tourism on economic growth in the Western Balkan countries: an empirical analysis. International Journal of Business and Economic Sciences Applied Research, 10(2).

Sequeira, T. N., \& Campos, C. (2005). International tourism and economic growth: a panel data approach.

Sequeira TN, Maçãs Nunes P (2008) Does tourism influence economic growth? A dynamic panel data approach. Appl Econ 40(18):2431-2441

Shaheen, K., Zaman, K., Batool, R., Khurshid, M. A., Aamir, A., Shoukry, A. M., ... \& Gani, S. (2019). Dynamic linkages between tourism, energy, environment, and economic growth: evidence from top 10 tourism-induced countries. Environmental Science and Pollution Research, 26(30), 31273-31283

Shakouri B, Khoshnevis Yazdi S, Ghorchebigi E (2017) Does tourism development promote CO2 emissions? Anatolia 28(3):444-452

Sherafatian-Jahromi R, Othman MS, Law SH, Ismail NW (2017) Tourism and $\mathrm{CO} 2$ emissions nexus in Southeast Asia: new evidence from panel estimation. Environ Dev Sustain 19(4):1407-1423

Shi, H., Li, X., Zhang, H., Liu, X., Li, T., \& Zhong, Z. (2019). Global difference in the relationships between tourism, economic growth, $\mathrm{CO} 2$ emissions, and primary energy consumption. Current Issues in Tourism, 1-16.

Sokhanvar A (2019) Does foreign direct investment accelerate tourism and economic growth within Europe? Tourism Management Perspectives 29:86-96

Sokhanvar, A., \& Jenkins, G. P. (2021). Impact of foreign direct investment and international tourism on long-run economic growth of Estonia. Journal of Economic Studies.

Solarin SA (2014) Tourist arrivals and macroeconomic determinants of $\mathrm{CO} 2$ emissions in Malaysia. Anatolia 25(2):228-241

Stefănica M, Butnaru GI (2015) Research on tourists' perception of the relationship between tourism and environment. Procedia Economics and Finance 20:595-600

Su Y, Cherian J, Sial MS, Badulescu A, Thu PA, Badulescu D, Samad S (2021) Does tourism affect economic growth of China? A panel Granger causality approach Sustainability 13(3):1349

Tang, Z., Bai, S., Shi, C., Liu, L., \& Li, X. (2018). Tourism-related $\mathrm{CO} 2$ emission and its decoupling effects in China: a spatiotemporal perspective. Advances in Meteorology, 2018.

Tecel A, Katircioğlu S, Taheri E, Bekun FV (2020) Causal interactions among tourism, foreign direct investment, domestic credits, and economic growth: evidence from selected Mediterranean countries. Port Econ J 19(3):195-212

Tu J, Zhang D (2020) Does tourism promote economic growth in Chinese ethnic minority areas? A nonlinear perspective. Journal of Destination Marketing \& Management 18:100473

UNWTO. (2015). Tourism and the sustainable development goals.

Usman O, Bekun FV, Ike GN (2020) Democracy and tourism demand in European countries: does environmental performance matter? Environ Sci Pollut Res 27(30):38353-38359

Wickremasinghe, G. B., \& Ihalanayake, R. (2006). The causal relationship between tourism and economic growth in Sri Lanka: some empirical evidence. WP2006. 10, School of Applied Economics, Victoria University.

WTTC. (2019). Economic impact report, World Travel and Tourism Council. https://wttc.org/Research/Economic-Impact.

Yazdi SK, Salehi KH, Soheilzad M (2017) The relationship between tourism, foreign direct investment and economic growth: evidence from Iran. Curr Issue Tour 20(1):15-26

Zaman K, Moemen MAE, Islam T (2017) Dynamic linkages between tourism transportation expenditures, carbon dioxide emission, energy consumption and growth factors: evidence from the transition economies. Curr Issue Tour 20(16):1720-1735 
Zaman K, Shahbaz M, Loganathan N, Raza SA (2016) Tourism development, energy consumption and environmental Kuznets curve: trivariate analysis in the panel of developed and developing countries. Tour Manage 54:275-283

Zhang L, Gao J (2016) Exploring the effects of international tourism on China's economic growth, energy consumption and environmental pollution: evidence from a regional panel analysis. Renew Sust Energ Rev 53:225-234

Zhang, J., \& Zhang, Y. (2020). Tourism, economic growth, energy consumption, and $\mathrm{CO} 2$ emissions in China. Tourism Economics, 1354816620918458 .
Zhang S, Liu X (2019) The roles of international tourism and renewable energy in environment: new evidence from Asian countries. Renewable Energy 139:385-394

Publisher's note Springer Nature remains neutral with regard to jurisdictional claims in published maps and institutional affiliations. 